I placed my captive in a glass vase, and his having selected the side of the glass for burrowing (probably from the glass forming one firm side to the work), enabled me to watch every movement; the sand appeared to be passed to the mouth of the hole by the legs and false legs, when it filled round the body and filled in as the animal passed downwards. The antennæ are delicately sensitive. I believe this sensitiveness depends on the sense of touch : the slightest contact with them sets the animal in motion (and this when it is buried some depth), using every exertion to burrow deeper. It is evidently a night-feeding genus, as it remained buried and inactive during the day, but the state of the sand in the tank in the morning proved that it had not been idle during the night.

From these facts I am justified in stating that Nika edulis is a burrowing species (if not of a burrowing genus), and that its burrowing is only by day to hide itself from its enemies, and not to procure food.

The description I have given of the colouring of this species will be found to be different from that given by Risso, as stated by Mr. Milne-Edwards. I should have great diffidence in differing from these eminent naturalists had I not imagined that their descriptions might have been taken from cabinet specimens. Had I waited to describe my specimen until after its death, I must have described it as it now is, namely, flesh-red; I find all the thinner-shelled Crustacea change more or less of a flesh-red, with the exception of the Crangonida.-Proc. Zool. Soc., April 22, 1856.

\title{
NAUCRATES DUCTOR.
}

To the Editors of the Annals of Natural History.

Falmouth, November 1, 1856.

Gentlenen, -A shoal of the Naucrates ductor, Cuv, made its appearance in shallow water, Custom House Pier, on Friday afternoon, Oct. 31, 1856, and more than three dozen of them were caught in nets, baskets, \&c., by persons on the beach. I have procured species of this interesting fish every year during my residence in this neighbourhood.

I am, Gentlemen, yours truly, W. P. Cocks.

\section{On Peculiar and Quasi-spontaneous Movements of the Plasmatic Cells of eertain Animals. By Prof. KöLliker.}

I have just observed at Nice, upon a fine animal of the family of the compound Ascidians, which according to M. Milne-Edwards has not yet been described, a very peculiar fact, namely, movements of the cells which occur in great number in the gelatinous substance common to the whole bunch and formed of cellulose. These cells, which are round or stellate and of very various forms, have, in the living animal, a slow, but easily perceptible movement, consisting in a constant change of form, so that the same cell, which was at one time round, becomes stellate or fusiform in different degrees, by the 
formation of two or several prolongations, often very long and even branched, returning subsequently to the round form which it had at the commencement. This movement, which is constantly observed in all these cells, although slow, is nevertheless pretty strong, and I have even several times observed cells which changed their position by the formation of processes, the whole presenting a considerable resemblance to the movement of an Actinophrys or Amoba. As in these animals, the contents of the cells also took part in the movement, and it was easy to see that these granulations passed sometimes into the processes, returning afterwards into the body of the cells, so that the change of form of the cells is accompanied by a movement of all the parts of which they consist, which may probably be intimately connected with the chemical and vital phonomena which are accomplished in these cells as well as in all the others.

Having observed these movements, it occurred to me that it was possible that many stellate cells exhibited similar movements, especially as something of the same kind has already been seen in the pigmentary cells of the Frog, and I set myself to examine the plasmatic cells or corpuscles of the conjunctive tissue. As these observations were made during the last days of my stay at Nice, I cannot give them the extent which I desired; however, I was fortunate enough to see that the plasmatic cells of the gelatinous conjunctive tissue of the head of the Torpedo, and the stellate cells of the gelatinous substance of the body of Cassiopeia borbonica, also exhibit movements similar to those which I have just described, and I do not doubt that it will be found that this phænomenon has a considerable extent, and even some physiological importance.-Comptes Rendus, Oct. 27, 1856, p. 794.

\section{Description of a New Species of Actinia from the Devonshire Coust. By E. W. H. Holdsworth.}

When contracted, the body forms a rounded button about $\frac{3}{4}$ of an inch in diameter, but in full expansion it is generally elongated to the extent of $2 \frac{1}{2}$ inches, and terminates in a somewhat cup-shaped disk about $1 \frac{1}{4}$ inch wide, and having its extended edges frequently thrown into irregular festoons. The tentacula, about 150 in number, are arranged in four or five series, as in most of the group to which this species belongs; the first row contains twenty-five arms, about half the length of the diameter of the disk, and moderately stout; the others gradually diminish in size as they proceed outwards, their numbers at the same time increasing; but the irregular manner in which they are placed renders it difficult to enumerate the contents, or to determine the limits of any one of the series. The disk is of a uniform olive-brown without any superficial markings, - the appearance of radiating lines, sometimes visible, being only the upper edges of the internal septa showing through the transparent skin; the mouth opens transversely, and displays a regular crenation of its pink lining membrane. The tentacula are of a reddish purple, and entirely destitute of rings or other marking; they present a remarkAnn. \& Mag. N. Hist. Ser. 2. Vol. xviii. 